\title{
PReS-FINAL-2280: Lupus disease activity in a pediatric Colombian cohort with systemic lupus erytematosus
}

\author{
AS Diaz Maldonado*, A Monje Gaitan, N Gamba, F Gonzalez \\ From 20th Pediatric Rheumatology European Society (PReS) Congress \\ Ljubljana, Slovenia. 25-29 September 2013
}

\section{Introduction}

Systemic Lupus Erythematosus (SLE) is disease which may have severe and variable activity in the pediatric population.

\section{Objectives}

compare the index of activity in two times at cohort of pediatric patients with SLE.

\section{Methods}

Analytic descriptive study. 89 patients with diagnosis SLE (1986 ACR criteria) from a rheumatology center at a pediatric hospital were evaluated at the time of diagnosis and twelve months after. Medical records were reviewed registering the following variables: score SLEDAI, Antinuclear antibodies (ANAs), Anti-DNA antibodies and complement C3 and C4 levels. Analysis was done through parametric and non parametric tests to compare means and proportions using STATA11. Shapiro-Wilk and Wilcoxon tests (non-normally distributed data) were applied.

\section{Results}

Median score SLEDAI at the time of diagnosis was 23 ( $\min 4 \max 61)$; after 12 months it was 4 ( $\min 0 \max$ 31) $(\mathrm{p}=0.001)$. Antinuclear antibodies (ANAs) reactivity at the diagnosis was $88,1 \%$; after 12 months it was $6,67 \%$ $(\mathrm{p}=0.17)$. Anti-DNA antibodies reactivity at the diagnosis was 66,7\%; after 12 months it was $56,41 \%$ (p = 0.01 ). C3 level was diminished in $67,95 \%$ of patients at the diagnosis; after 12 months it was diminished in $33,3 \%$ of patients $(\mathrm{p}=0.01)$. C4 level was diminished in

\footnotetext{
Reumatologia Pediatrica, Hospital de La Misericordia, Bogota, Colombia
}

$71,7 \%$ of patients at the diagnosis; after 12 months it was diminished in $40 \%$ of patients $(\mathrm{p}=0.01)$.

\section{Conclusion}

Statistical significance was documented regarding score SLEDAI, Anti-DNA antibodies reactivity, hypocomplementemia for the time of diagnosis and twelve month follow-up. This suggests that improvement in disease activity was due to the established treatment.

\section{Disclosure of interest}

None declared.

Published: 5 December 2013

doi:10.1186/1546-0096-11-S2-P270

Cite this article as: Diaz Maldonado et al.: PReS-FINAL-2280: Lupus

disease activity in a pediatric Colombian cohort with systemic

lupus erytematosus. Pediatric Rheumatology 2013 11(Suppl 2):P270.

Submit your next manuscript to BioMed Central and take full advantage of:

- Convenient online submission

- Thorough peer review

- No space constraints or color figure charges

- Immediate publication on acceptance

- Inclusion in PubMed, CAS, Scopus and Google Scholar

- Research which is freely available for redistribution

Submit your manuscript at www.biomedcentral.com/submit
() Biomed Central 